\title{
The New Concept of Ripening Fruit in the Garden
}

\author{
SA Rodiko* \\ Department of soil science, Russia
}

Submission: February 22, 2017; Published: March 16, 2017

"Corresponding author: SA Rodiko, Department of soil science, FSEI HE Mich GAU, Michurinsk, Tambov, Russia, Email: rsa_rih@mail.ru

\begin{abstract}
Summary
Currently, there are two major unresolved problems in cleaning and storage of apples in horticulture: determination of the optimal term removal of the fruit in the garden and the development during storage browning the skin of some varieties of apples. Deviation from the optimal term removal of fruits in the early and late at night leads to a deterioration of their quality and keeping quality during storage. It was found that the process of fruit ripening is subject to cyclical development, changes in the components that characterize the physiological state of the fruit occurs with some frequency, especially noticeable on the stage of a removable maturity. For apples multiobjective evaluation maturity maturity indices used, for example, apples $\mathrm{AC}$ resistivity tissue at two frequencies, a low of $1 \mathrm{kHz}$ and a high of $10 \mathrm{kHz}$; variable chlorophyll fluorescence peel apples at a wavelength $685 \mathrm{~nm}$; transpiration fruit gravimetric method. Measurements were carried out every day or every other day, one hour after the removal, at the same time. When measuring the surface area is determined as a solar apple, illuminated on a tree in the garden of direct sunlight and shadow, illuminated only by ambient light. The optimum period is characterized by the removal of the minimum intensity of physiological processes in the fruit. Showing new methodological approaches to the solution of the major problems in cleaning and storage of apples. It is expected that it will take a certain amount of time cycles, so the apples are ripe. On the duration of ripening influence temperature and humidity conditions of the growing season. New methods of assessment of the maturity of apples during harvest time in the garden. The minimum intensity of physiological processes in the fruit is a signal to the harvest of the fruit.
\end{abstract}

Keywords: Apples; Ripening; Eat; Cycles; Physiology; Processes; Chlorophyll fluorescence; Electrical resistance; Transpiration

\section{Introduction}

It is known that a departure from the optimal time removal of fruits in the early and late at night leads to a deterioration of their quality and keeping quality [1]. The main uncontrollable factors affecting ripening are: ambient temperature, solar radiation, humidity, rainfall.

Some authors describe the current trends in the definition of the optimal period for storing removal fruits, without making reference to the famous work in this area [2]. None of the examined indicators of the degree of maturity authors failed to describe the definition of an optimal removal period, neither the content of starch in apple tissue or hardness tkni nor content of endogenous ethylene in apples, nor even the reflection spectra. Also, foreign works not give us the answer to this question. Critical analysis of these approaches is described in detail in the monograph [3].

Due to the fact that scientists have not yet been developed reliable and valid methods for determining the optimal time removal of apples in the garden, agronomists remove apples from the trees, guided above all organizational tasks, then a rough idea of the timing of removal.

Thus, at present there are two major unresolved problems in cleaning and storage of apples: the definition of optimum term removal of the fruit in the garden and the development during storage browning the skin of some varieties of apples [4]. Previously, our data were obtained showing the solar radiation effect on the exclusion of browning the skin [5]. It is also found that the process of fruit ripening is subject to cyclical development, changes in the components that characterize the physiological state of the fruit occurs with some frequency, especially noticeable on the stage of a removable maturity.

The studies were conducted on the basis of new methodological concepts, consisting in the fact that studied the whole fruit, which does not violate the physiological processes associated with photosynthesis, water exchange and breathing. 
The purpose of this article: show new methodological approaches to the solution of the major problems in cleaning and storage of apples.

\section{Technique}

The object of research is the process of ripening apples Antonovka ordinary shot of a tree during their maturation, for the duration of approximately two weeks. Removing the produced in horticultural farms in the area of Michurinsk. It should be noted that the phenomena and laws found in this variety, typical of other varieties of apple trees. Measurements were carried out every day or every other day, one hour after the removal, at the same time. As maturity indicators measure chlorophyll content in the skin of the fruit from the coefficients of light reflection surface thereof. When measuring the surface area is determined as a solar apple, illuminated on a tree in the garden of direct sunlight and shadow, illuminated only by ambient light. The coefficients of reflection of light at wavelengths determined by $700 \mathrm{~nm}$ - and chlorophyll absorption region of 750nm - which do not absorb light chlorophylls [3]. As an indicator of maturity of the apples used the ratio R750/R700 coefficients.

For multicriteria evaluation apple ripeness using maturity indicators, such as the electrical resistance of the tissue of apples alternating current at two frequencies, for example, a low of $1 \mathrm{kHz}$ and a high of $10 \mathrm{kHz}$ [6], the fluorescence of chlorophyll variable peel apples on the emission wavelength of 685nm [7], transpiration fruit gravimetric method [8]. These methods are non-destructive and characterize the physiological state of the fruit. Multi-criteria evaluation is important for the reliability and reproducibility of the measurement results to determine the optimum removal period. The optimum period is characterized by the removal of the minimum intensity of physiological processes in the fruit $[3,4]$.

The fruits per day pickup lay deposited in camera mode: 3-4 ${ }^{\circ} \mathrm{C}$ temperature, relative humidity $85-90 \%$. After four months of storage of fruits were analyzed for the development of their browning the skin (sunburn) of the surface according to [9].

\section{Results and Discussion}

On ripening apple fruit affected by temperature growing season. In addition, important are the light and the dark periods, i.e. cycles, characterized by variations in temperature and the change of day and night. And the apple to ripen must collect a certain number of time cycles. In the past, given that it will take some time for ripening, considered the number of days from flowering. With an average temperature of air must pass a certain number of cycles to the apples are ripe. The number of cycles can be different for different varieties of apple trees. But it often happens that the amount of active air temperatures exceed a mean annual value, or get to the middle. Start of hydrolysis of starch in apple tissue indicates the beginning of ripening of apple. This method in combination of other non-destructive methods to determine the optimal removal of the offensive term.
If, for example, in the summer there was a high temperature, then the apples were forced to mature early, are not getting the required number of cycles (2010), whereas the mean temperature of the apples are ripening temperature conditions longer and collect the required number of cycles, and be of good quality, having Sun least during storage, stored longer (2004). Especially, when the growing season along with the cool conditions of growing fruit trees, complemented by significant rainfall, both in 2003, resulting in optimal time pickup came in mid-September, and the apples were stored without damaging sunburn until February, with high taste.

Thus, it is rare that the conditions of temperature, soil moisture, and the number of cycles at the time of removal rate of apples reached the required (optimal) values. The main factors (conditions) are the temperature and humidity of the soil. The temperature may be either low or high, and regardless of the number of cycles, or apples and ripen them we obtain tan during storage, degradation or removal from the later period. At high temperatures, apples, before ripening, have to have a smaller tan, but due to the fact that they do not gain the necessary number of cycles are tan and optimum time after removal rate (in which too tan) are decomposed, i.e., aging, caused by high temperatures.

Temperatures should be the base (of the class), at which the best quality of fruits and determine the number of cycles. For varieties Antonovka ordinary sum of active temperatures during these weather conditions it must be within $2275-2375{ }^{\circ} \mathrm{C}$ the first decade of September. By providing irrigation or rainfall $500-600 \mathrm{~mm}$, evenly distributed over the months of the growing season.

To determine the optimal term removal using apples maturity indicators are the minimum value of the intensity of physiological processes.

\section{Conclusion}

Showing new methodological approaches to the solution of the major problems in cleaning and storage of apples. It is expected that it will take a certain amount of time cycles, so the apples are ripe. On the duration of ripening influence temperature and humidity conditions of the growing season. New methods of assessment of the maturity of apples during harvest time in the garden. The minimum intensity of physiological processes in the fruit is a signal to the harvest of the fruit.

\section{References}

1. Ignatiev BD (1982) Long-term storage of fruits. In: Ignatiev BD, et al. (Eds.), BD Ignatieff. - Kiev - Vintage, pp. 160.

2. Karpov SB (2011) Modern trends in determining the optimal time for the removal of fruit storage. 2 (Part 2): S79-S84.

3. Rodikov SA (2009) Methods and apparatus analyzes maturity of apples. pp. 216.

4. Rodikov SA (2011) Optimal timing for removal of apples and browning of the surface - the main problem of storage. Coll Scien tr 28(2): 184190. 
5. Rodikov SA (2001) Rapid diagnosis of mature apples. 1: 9-12.

6. Rodikov SA (2009) Application of alternating electrical current to control the quality of apples. 2: 68-70.

7. Rodikov SA (2009) The fluorescence of chlorophyll surface of apples during ripening and storage. 8: S33-S34.

This work is licensed under Creative Commons Attribution 4.0 License

DOI: 10.19080 /ARTOAJ.2017.04.555650
8. Rodikov SA (2016) Methods of measuring transpiration of apple / SA Rodikov // improving the efficiency of the domestic gardening with the aim of improving the structure of power of the Russian population: mat. Scient. Conf. (4-6 September 2015 Michurinsk-science town of the Russian Federation, the Day of the gardener). Michurinsk-science town of the Russian Federation, Russia, pp. 217-220.

9. Rodikov SA (2003) Assessment of apples in storage Sun. 9: 69-70.

\section{Your next submission with Juniper Publishers will reach you the below assets}

- Quality Editorial service

- Swift Peer Review

- Reprints availability

- E-prints Service

- Manuscript Podcast for convenient understanding

- Global attainment for your research

- Manuscript accessibility in different formats ( Pdf, E-pub, Full Text, Audio)

- Unceasing customer service

Track the below URL for one-step submission https://juniperpublishers.com/online-submission.php 